\title{
Firm-Level Determinants of Corporate Social Responsibility: Evidence from Small and Medium- sized Enterprises in Ghana
}

\author{
Abraham Ansong \\ Department of Management, University of Cape Coast \\ Email: aansong@ucc.edu.gh
}

\begin{abstract}
This paper examined firm-level determinants of social performance among small and medium-sized enterprises (SMEs) in Ghana, using specific traits, such as firm age, firm size, financial performance, leverage and managerial competence. It contributes to our knowledge on how firm-level characteristics influence the corporate social responsibility (CSR) initiatives among SMEs. The study analysed primary data of 423 SMEs, using regression analysis. It documented positive relationships between managerial competence, financial performance and CSR, and a negative relationship between leverage and CSR. The thrust of the study is that, besides managerial competence, financial performance variables were far more important determinants of
\end{abstract}

the social performance of SMEs than non-financial ones. Therefore, it recommended that policy makers that desire active participation of the SME sector in addressing societal problems should institute measures that will improve their financial performance. These could include providing cheaper alternatives to accessing funds and maintaining a sustainable macroeconomic environment that support the financial prosperity of this sector. Finally, since it has been proven that managerial competence improves social performance, SME owner/managers are being encouraged to invest a lot of time and resources in sharpening their managerial competencies.

Keywords: SMEs, firm-level determinants, CSR; social performance, financial 
A. Ansong: Firm-Level Determinants of Corporate Social Responsibility: Evidence from Small and Medium-sized Enterprises in Ghana

determinants, non-financial

determinants, emerging economy 


\section{Introduction}

The concept of corporate social responsibility (CSR) has gained heightened attention from academics and practitioners in the wake of various scandals in recent times. Notable among them are the Volkswagen's emissions scandal, the Apple old iPhone slowdown and the Toshiba accounting scandal. These cases have contributed to a phenomenon that is described as a decade of moral decadence in business. Beyond everything else, it has been advanced that what businesses need most for their long-term survival and growth is an "ethical bailout" grounded on the tenets of CSR (Chih, et al., 2010). Some scholars (Chih, et al., 2010) have long argued that the responsibility of businesses extends beyond their owners and creditors to include several other groups and individuals who are adversely affected by business operations. For instance, Carroll's (1979, p. 500) observation is that "the social responsibility of business encompasses the economic, legal, ethical, and discretionary expectations that society has of organizations at a given point in time." Davis (1973, p. 312) opined that businesses should "accomplish social benefits along with the traditional economic gains that the firm seeks;" and Frederick (1986, p. 4) argued that "the fundamental idea of 'corporate social responsibility' is that business corporations have an obligation to work for social betterment." Acabado et al. (2019) posit that, to fully appropriate the value CSR creates for society, it is imperative for researchers and academics to pay attention to its determinants.

While extensive research has already been conducted in the area of CSR, most of these studies have concentrated on examining the nexus between corporate social performance and corporate performance (Ansong, 2017a; Ansong, 2017b; Bocquet et al., 2017; Saedi et al., 2015; Mishra \& Suar, 2010; Mackey et al., 2007; McWilliams \& Siegel, 2000; Waddock \& Graves, 1997). Margolis and Walsh (2003) have attributed the limited understanding of the concept of CSR to the over-emphasis on its impact on firm performance and there have been indeed recent calls 
from some scholars (for example, Walsh et al., 2003) for a more thorough theoretical and empirical investigations into the determinants of corporate social performance. Most of the studies that have responded to this call thus far have largely focused on how external variables, such as business cycles (Catalao-Lapes et al., 2016) and the pressure from external stakeholders (Benabou and Tirole, 2010; Darnall et al., 2012; Baron, 2012), influence firms' CSR initiatives. Empirical works that have addressed the firm-level determinants (Baldini et al., 2018; Lourenco \& Branco, 2013; Iannou \& Serafeim, 2012; Artiach et al., 2010; Reverte, 2009; Wanderley, Lucian, Farache, \& De Sousa Filho, 2008; Stanwick \& Stanwick, 1998; Roberts, 1992), largely ignored the SME sector.

The study of Campbell (2007) is accredited with the institutional theory on CSR, which makes some propositions, indicating the conditions that are likely to influence the extent to which firms perform socially. The conditions proposed by Campbell (2007) include the state of the economy, the degree of rivalry among firms, institutional factors and firm-level characteristics (see also Jones, 1999; Shleifer, 2004). This paper concentrates on how firm-level characteristics of SMEs in a developing economy influence their social performance. Jones (1999) rates the SME sector higher than larger firms in the execution of noninstrumental social responsibilities, because these firms are not subject to the financial hegemony and bureaucratic controls that tend to hinder CSR practices among larger firms. Jones (1999) advanced that SME owners/managers have the flexibility to imprint their personal values on their businesses and, hopefully, some of these values may promote the ideals of being good corporate citizens while pursuing financial prosperity. This makes the SME sector an important area for empirical studies in order to enrich the CSR discourse.

It is also imperative to study the concept of CSR from the perspective of emerging economies, because of the view 
that such economies are usually characterized by weak governance and institutional structures (Cambell, 2012). This makes them more dependent on the private sector to spur socio-economic development. In many developing countries, the SME sector constitutes a vast majority of businesses and accounts for a large share of overall employment in the private sector. Given the significant contributions of this sector, it would be inappropriate for researchers to ignore it in their investigations (Spence \& Lozano, 2000). Finally, the study focuses on the firm-level characteristics as the firm is the ultimate target for any action designed to promote CSR (Jones, 1999). Since initiatives at other levels are generally directed at the firmlevel, a proper appreciation of firm-level attributes is necessary to assist firms drive strategic value from CSR (Udayasankar, 2008).

This paper makes two relevant contributions to the extant literature on CSR. First, it contributes to our understanding of firm-level determinants of CSR among SMEs. Second, it empirically examines the relationship between firm-level factors and CSR in an emerging country context where governance and institutional structures are weak relative to advanced economies. The next section of this paper reviews literature and develops hypotheses on the firmlevel determinants of CSR, after which the methodology that was employed in conducting the study is explained. It proceeds to the presentation and analysis of results. Finally, it concludes by making recommendations.

\section{Literature Review}

The instrumental theories emphasise the notion that the main purpose of firms is wealth creation and as such firms should only embark on social activities that are consistent with wealth creation (Friedman, 1970). On the other hand, integrative and ethical theories hold a different position. Integrative theorists advocate that business organizations utilize societal resources to support their survival and growth and, hence, they should assist in addressing societal problems and challenges even if this does not necessarily lead to the maximization of 
shareholders' wealth (Preston \& Post, 1975; Garriga \& Mele, 2004). In a similar vein, ethical theorists believe ethical values define the relationship between business organizations and society. Hence, ethical considerations must supersede other factors when a firm decides to embark on CSR initiatives (Freeman, 1984. Jones (1999) drew attention on SMEs as a sector more prone to carrying on non-instrumental CSR and, hence, worthy of empirical investigation. Again, Campell (2007) posits that firm-level characteristics have the potential to influence the extent to which firms engage in CSR initiatives. Hence, this study examines the relationship between traits, such as firm size, firm age, financial performance, leverage and managerial competence and the social performance of firms.

\section{Firm Size and CSR}

Several studies have offered different explanations as to how and why firm size affect social performance of corporations. Based on organisation theory, some have suggested that larger organisations tend to have the administrative structures and systems in place, which then create the management architecture necessary for improved social performance (Brammer \& Millington, 2006). In contrast, others are of the view that the bureaucratic nature of larger firms rather inhibits them from becoming socially responsive (Jones, 1999). Jones (1999: 169) posits that organisational inflexibility is more likely to be associated with firm size and, corollary to this, "noninstrumental socially responsible behaviour is simply not viable in the decision making and control systems of capitalist-bureaucratic organisations."

The power explanation (Pfeffer \& Salancik, 1978; Meznar \& Nigh 1995) emanating from sociological literature expounds on how corporations deal with pressure from societal expectations with rather conflicting conclusions. On one hand, it is assumed that larger firms are more likely to be pressurised due to their visibility to invest more in CSR activities. By comparison, SMEs are likely not to exhibit socially responsible 
behaviour, since they are less visible and may profit little from CSR initiatives. On the other hand, other scholars (e.g., Meznar $\&$ Nigh, 1995) are of the view that given the higher bargaining power of larger firms, they are better positioned, relative to SMEs, to resist any influence to commit to CSR practices they are not ready for. As a result of this, large firms are less likely to be socially responsive.

Based on contingency theory and organisational economics, Wicket et al. (2016) reasoned that the cost implications associated with managing largesized firms could negatively influence the extent to which such firms invest in CSR activities. The ownership structure of large firms also tends to limit the extent to which such firms are socially responsible. Large firms are usually accountable to powerful shareholders, creditors and to the whims of financial markets (Mintz $\&$ Schwartz, 1990). The primary motive of these stakeholders is to earn optimum return on their investment. Hence, they are less likely to be tolerant of socially responsible behaviours that do not positively impact on a firm's competitive position. This limits the opportunities for management of such firms to act in socially responsible ways. However, owners/managers of SMEs have the laxity to impact their firms with their personal values, which may include being socially responsible, in addition to the pursuit of personal wealth (Jones, 1999; Ansong, 2015).

The impact of firm size on corporate social performance is also connected to the issue of access to resources (Brammer \& Millington, 2006). It is a wellaccepted view that larger firms tend to enjoy greater resourceslack, and this positively influences their CSR commitment (Johnson \& Greening, 1999). On the contrary, SMEs often do not have access to financial resources that will empower them to become more socially responsible.

However, Madueno, Jorge, Conesa and MartínezMartínez (2016) posit that SMEs carry out more CSR practices than they acknowledge, a phenomenon referred to as silent social responsibility. Overall, it has been argued that firm size can affect 
strategic motivation, thereby having a positive influence on social performance (Adams \& Hardwick, 1998; McElroy \& Siegfred, 1985). Empirically, Madueno et al. (2016) and Acabado et al. (2019) found a positive relationship between firm size and corporate social responsiveness and philanthropy. It is deemed that in an emerging economy where access to and effective utilization of financial resources is key to the survival of SMEs, larger firms would have more laxity to spend on social initiatives. Based on the arguments raised above, it is anticipated that larger firms are much more likely to undertake CSR activities with ease relative to SMEs (Baumann-Pauly, Wickert, Spence \& Scherer, 2013; Lepoutre \& Heene, 2006). Hence, it is hypothesized that:

H1: Firm size positively influences the social performance of SMEs

\section{Firm Age and CSR}

There have been limited theoretical explanations as to how firm age impacts on corporate social performance. However,
Jawahar and McLaughlin (2001) provide insight into how firm age can influence CSR initiatives based on the organisational life cycle approach. They reasoned that while companies are required to equally satisfy the needs of all their stakeholders, it is practically impossible to do so at the same time. "Instead, they are likely to fulfil economic and all noneconomic responsibilities of some primary stakeholders, not others, and, over time, to fulfil responsibilities relative to each stakeholder to varying extents" (Jawahar \& McLaughlin, 2001: 397). This is so because the needs of these stakeholders do not arise at the same time and different stakeholder groups tend to wield different degrees of influence and power on an organisation across its life cycle stages.

The foremost work of Cochran and Wood (1984) reasoned that firms with older assets, which might have been manufactured in an era of weak regulatory business environment, are more likely to be seen as being less socially responsible, because of possible emissions from these assets. The reality, however, is 
that management of such firms might have exerted a lot of energy and initiatives aimed at attaining a cleaner environment. Thus, the mere fact that an older firm might be possessing older assets that are less environmentally friendly can lead to higher costs in meeting new social demands and, at the same time, may be viewed as being less socially responsible.

Another explanation is that management of older firms are less responsive in adapting to social change (Cochran \&Wood, 1984). On the contrary, Roberts (1992) advanced that as a firm matures, it is somewhat compelled to maintain its reputational record of being a good corporate citizen. The expectations of stakeholders regarding sponsorship and involvement could inhibit any changes in corporate strategy as withdrawal from such commitments could signal to stakeholders that the firm expects financial or managerial disturbances. Similarly, AlGamrh et al. (2016) advanced that older firms tend to have a better understanding of the challenges and needs of their environment and such knowledge tends to induce them to be more socially responsible, since they are expected to behave as corporate citizens. Again, older firms are more aware of the positive outcomes of CSR initiatives, such as customer loyalty, attraction of talented employees, less lawsuits and so on, hence, they are more likely to embark on such activities than younger ones.

Withisuphakorn and Jiraporn (2016) opined that older firms tend to be more financially stable and cashflow than younger ones. This enables them to embark on more CSR initiatives. However, the fact that they are also already financially sound could discourage them from such investments. Older firms might have built the reputational capital that comes as a result of being socially responsible and, thus, they may have little drive for engaging in CSR activities relative to younger ones.

Empirically, Godos-Díez, et al. (2011) documented that once a firm initiates socially responsible activities, it is compelled to implement them due to the firm's desire to meet the expectations of its stakeholders. 
From the discussions above, it is expected that older SMEs in emerging economies are more likely to engage in social responsibility actions, because of their quest to maintain their credibility and reputation. Scholars (e.g., Diamond, 1989) have largely associated firm age to firm reputation among smaller firms, because of their ability to survive the critical start-up years. Hence, it is hypothesized that:

H2: Older SMEs are more likely to be socially responsible

\section{Financial Performance and CSR}

The main thrust of the slack resource theory and resource-based view is that the financial condition of an organisation is a key determinant of the amount and kinds of activities the organisation can engage in (Campbell, 2007; Waddock \& Graves, 1997; Buchholtz et al., 1999). This implies that firms with enough financial resources are better positioned to engage in CSR initiatives. On the other hand, good management theory admonished managers to pursue activities that will address the concerns of the stakeholders without necessarily considering their financial resources. It is believed that, by doing so, the reputation of the organisation will be enhanced, and this would, consequently, lead to better financial performance (Campbell, 2007; Waddock \& Graves, 1997; Fauzi \& Idris, 2009).

Campbell (2007) has observed that profitable firms tend to have more resources to spare for socially responsible initiatives than less profitable ones. As a result, it is expected that business organisations will be less likely to commit financial resources to socially responsible activities in instances where they are experiencing relatively weak financial performance (Waddock \& Graves, 1997). This proposition is much stronger among SMEs, since social performance is also related to the issue of access to resources (Brammer \& Millington, 2006). Larger firms are associated with greater resource-slack, and this significantly influences their commitment to CSR activities (Johnson \& Greening, 1999). This position is supported by 
Withisuphakorn and Jiraporn (2016). They argued that firms that are financially sound and have enough cashflows tend to engage more in CSR activities.

On the contrary, SMEs often have constrained or inadequate financial resources, which tend to negatively impact on their ability to pursue CSR initiatives. It has also been advanced that firms with poor financial performance do not embrace government directives that emphasise the need for firms to embark upon CSR practices. This is because they believe such regulatory measures would compel them to invest their meagre resources in activities, they deem to be unproductive, thereby worsening their already precarious financial position (Smith, 1994). Several empirical studies (e.g., Cochran \& Wood, 1984; Lin, et al., 2009) have reported that financial performance has a positive effect on social performance. It, therefore, follows that financial performance is expected to be positively related to the extent of a firm's social performance. Thus, it is hypothesized that:

\section{H3: Financially sound SMEs are more likely to be more socially responsible}

\section{Financial Leverage and CSR}

Financial leverage has been explained as funds taken from outside parties, like companies and other financial institutions, to undertake business ventures (Sahut et al., 2016). The stakeholder theory (Jensen, 2002) and capital structure theories provide some explanations as to how financial leverage could influence the extent to which a firm can engage in CSR initiatives (Mishra \& Modi, 2013). Jensen (2002) calls for a balance in managerial decision making in the attempt by management to meet the expectations of both investing and non-investing stakeholders. He argues that it will be counterproductive to ignore the needs of investing stakeholders through the acquisition of unsustainable levels of debts in the bid to satisfy the needs of non-investing stakeholders. The consequences of CSR activities for highly indebted companies could be negative, because of the possible negative reactions from some key 
stakeholders, such as creditors and suppliers.

Even though it has been suggested that CSR investments strengthen a firm's relations with its stakeholders, this is dependent on the financial leverage position of the enterprise (Harrison \& Combs, 2006). Titman (1984) advanced that key stakeholders are usually mindful of the indebtedness levels of firms. This is because the leverage position of companies can influence their ability to honour their financial obligations as and when they fall due. Purushothaman et al. (2000) posited that the close relationship between high-leveraged firms and creditors tends to limit the amount of resources they devote for socially responsible actions. Also, Zweibel (1996) reasoned that excessive company debt increases interest expenses, which discourages investment in CSR among firms that have the object of maximising shareholders' wealth. Moussu and Ohana (2016) add that the debt pressure acts as a brake in discouraging investments, which are valuable both for society and firms.
However, Brammer and Millington (2005) also posit that high leverage negatively affects the reputation of a firm, and this puts pressure on firms in this state to intensify their CSR initiatives to improve their image. It is anticipated that the cost implications of having a lot of debts could negatively influence the ability of SMEs to perform their social responsibilities. Empirically, Harrison and Combs (2006) provided evidence on how financial leverage influences managerial decisions in social performance-related areas, such as employee treatment, product issues, environmental protection, diversity performance and community relations. Some scholars (Moussu \& Ohana, 2016; Purushothaman et al., 2000; Zweibel, 1996) have also reported a negative relationship between leverage and CSR practices. Thus, the following hypothesis is proposed:

H4: Leverage is negatively related to social performance of SMEs 
Managerial Competence and CSR

Agency and stewardship theories provide the theoretical explanation for the differences in importance managers attach to CSR activities. Agency theory views managers as agents who would essentially seek to maximize their own utility, even at the expense of the value of the firm (Jensen \& Meckling, 1976). It is deemed that managers with such orientation are less likely to be interested in socially responsible investments, since this would not explicitly enhance their personal wealth. On the contrary, the stewardship theory portrays managers as stewards of firms (Davis et al., 1997). Stewards are expected to defend the welfare of all stakeholders and make decisions that address the concerns of the majority and not those of only shareholders. The theory is premised on the fact that the most efficient way to satisfy all stakeholders with conflicting interests is to maximize the longterm value of the firm (Hernandez, 2008). Some scholars (e.g. Waddock \& Graves, 1997) have documented that firms' long-term value can be enhanced through managerial competence and CSR. In practice, the role played by top managers in promoting social initiatives is extremely important (Quazi, 2003; Swanson, 2008). Socially responsible firms are the creation of socially responsible managers who are willing sometimes to sacrifice personal and corporate ambitions in favour of socially responsible actions (Hunt et al., 1990). Indeed, it is the responsibility of top managers to incorporate ethical and social responsibility values into the organisational culture and strategy (Waldman et al., 2006; Singhapakdi et al., 2008). It has been argued that, to ensure the consistent and successful pursuit of CSR initiatives, it is not enough to develop effective CSR structures and policies (Harris \& Crane, 2002; Holton et al., 2010; Mamic, 2005), rather, what is most needed is developing the competencies and skills of managers (Ansong, 2017c; Lans et al. 2014; Wals \& Jickling, 2002). According to Belkaoui and Karpik (1989), the underlying cause of an effective implementation of social 
performance policy that delivers long-term value to firms is management's competence. Management with the competence to make a company profitable also has the knowledge and understanding of social responsibility, which leads to addressing more social and environmental concerns. Following from the above discussion, it is hypothesized that:

H5: Managerial competence positively influences the social performance of SMEs.

\section{Methodology}

The

quantitative approach was adopted for the study as it allows for generalisability and reliability. The populations of this study consisted of all registered SMEs with the National Board for SmallScale Industries (NBSSI) and the Association of Ghana Industries (AGI) in the Accra Metropolis of Ghana, a total of 2083 firms as of September 2013. Based on Krejcie and Morgan (1970), who assume an alpha of 0.05 and a $5 \%$ margin error, a sample of 423 SMEs, consisting of 254 medium-sized and 302 small-sized firms, were randomly selected for the study. The random sampling technique grants unbiasedness in the selection of respondents for the study. A close-ended questionnaire was used in collecting data from the owners/managers of SMEs in the Accra Metropolis of Ghana. A pilot study was conducted in February 2014 to validate the questionnaire. The questionnaire was administered to a sample of fifty SME owners/managers in the Sekondi-Takoradi Metropolis. This was intended to predict the expected response rate and identify any problems with the survey. The pilot recovered a response of 62 percent. All items showed a high level of internal consistency reliability.

A major limitation of the use of questionnaire was the possibility of method bias. Podsakoff, Mackenzie and Podsakoff (2012) opined that selfreported measures have the tendency of being affected by common method bias (CMB). This is due to the fact that there is usually an implicit social desirability associated with answering survey questions in a 
certain desirable pattern, causing indicators to share a common amount of variation (Kock \& Lynn, 2012), item characteristics (ambiguous items) and measurement context (Podsakoff, Mackenzie, Lee \& Podsakoff, 2003). This bias can lead to unsound conclusions, because it can inflate or deflate a given relationship among variables (Doty \& Glick, 1998). Because all measures were self-reported and collected from a single group of respondents (owners/managers of SME), the common method bias test was conducted to address this problem (Podsakoff et al., 2003). Descriptive statistics and regression analysis were employed in analysing the data. Multiple regression was adopted as it allows testing the predictive power of a set of independent variables on a continuous dependent variable (Pallant, 2015).

\section{Model}

This study adapted the model of Reverte (2008). The new model considers the relationship between CSR and firm age, firm size, leverage, managerial competence and financial performance. The inclusion of each variable in the model is informed by the theories used in the study. Thus, the model for the study takes the following form:

$C S R_{i}=\alpha_{i}+\beta_{1} F A_{i}+\beta_{2} F S_{i}++\beta_{3} L E_{i}$ $\beta_{4} M C_{i}++\beta_{5} F P_{i}+\varepsilon_{i}$

\section{(1)}

Where:

CSR represents corporate social responsibility; FA represents firm age; FS represents firm size; LE represents leverage; MC represents managerial competence; FP represents financial performance.

\section{Measurement of Variables}

This section provides explanation as to how the variables employed in this study were measured:

Dependent Variable

Corporate social responsibility (CSR) was measured based on Sweeney's (2009) scale. The scale took into consideration all the key CSR dimensions. Some of the specific CSR information that were covered involved energy 
conservation, supply of clear and accurate information and labelling of products and services and so on.

Independent Variables

Firm age was measured based on the number of years the business has been in operation. The number of employees was used as a proxy for firm size. The ratio of total assets to total debts measured the leverage of the firms. It is important to note that this ratio would reverse the interpretation of the direction of the regression output on leverage. Nakiyinga (2007)'s 14-item scale of managerial competence was adopted for the study. In line with previous studies in the SME domain, financial performance was subjectively measured. It has been argued that subjective measures of financial indicators are acceptable, because SMEs rarely keep financial records (see Sweeney, 2009; Man, 2011; Burton \& Goldsby, 2009).

\section{Results and Discussion}

Descriptive statistics
Table 1 summarizes the descriptive analyses of dependent and independent variables, reporting the mean, standard deviation, minimum and maximum statistics for the attributes of the firms included in the sample. The average extent to which the sampled firms engage in corporate social responsibility is 3.89. This shows that most of the SMEs, despite their size, were still actively pursuing CSR practices. Firm age has a mean of 14, while firm size, in terms of the number of employees, had a mean of 14.19. Financial performance has a mean value of 1.17 . This implies that the financial performance of the sampled SMEs was not encouraging. Managerial competence recorded a mean of 4.0478. This suggests that a lot of the SME managers have the requisite competence in running these businesses. Leverage (measured as total assets/total debts) indicates a mean value of 3.4161, suggesting that most of the SMEs do not employ a lot of debts in their operations. 
Table 1: Descriptive Summary Statistics

\begin{tabular}{|c|c|c|c|c|}
\hline Variable & Mean & Std. & Minimum & Maximum \\
\hline & & Deviation & & \\
\hline CSR & 3.8900 & 0.5900 & 1.0000 & 5.0000 \\
\hline $\begin{array}{l}\text { Managerial } \\
\text { competence }\end{array}$ & 4.0500 & 0.5200 & 1.0000 & 5.0000 \\
\hline $\begin{array}{l}\text { Financial } \\
\text { performance }\end{array}$ & 1.1700 & 0.3537 & 1.0000 & 3.0000 \\
\hline Firm age & 14.0000 & 13.3499 & 1.0000 & 70.0000 \\
\hline Firm size & 14.1915 & 12.1520 & 1.0000 & 65.0000 \\
\hline Leverage & 3.4161 & 0.9039 & 1.0000 & 5.0000 \\
\hline
\end{tabular}

Multicollinearity tests

Table 2 shows the multicollinearity tests results for the independent variables used in the study. The calculated VIF (Variance inflation factor) in all cases was less than 2, indicating that there is no multicollinearity problem for regression analysis (Fox, 1991).

Table 2: Multicollinearity Tests

\begin{tabular}{llll}
\cline { 1 - 1 } Variables & & Tolerance & VIF \\
\cline { 1 - 1 } Managerial competence & & 0.892 & 1.122 \\
Financial performance & & 0.693 & 1.444 \\
Firm age & 0.725 & 1.379 \\
Firm size & 0.718 & 1.392 \\
Leverage & 0.625 & 1.601 \\
\hline
\end{tabular}

Common Method Bias tests

To reduce the possibility of common method bias (CMB), both procedural and statistical measures are adopted (Mat Roni, 2014). The procedural method concerns the approach the data were collected, and the instrument is designed. To reduce the effect of $\mathrm{CMB}$ in this study, only previously tested scales were used (Alfes, Shantz, Truss, \& Soane, 2013). To reduce social desirability bias and evaluation 
apprehension, the survey stressed anonymity of respondents (Podsakoff et al. 2003; Mat Roni, 2014). In addition, statistical approach is also very important in controlling for CMB (Mat Roni, ibid).

According to Podaskoff et al (2003), the Harman's single factor test is the most widely used and simplest test in literature to control against CMB. With respect to the test, Podsakoff and Organ (1986) advanced that a single factor would emerge from a factor analysis or one general factor would account for most of the covariance in the independent and criterion variables if $\mathrm{CMB}$ was a serious problem. Mat Roni (2014) also adds that if the first component of the Total Variance Explained in a factor analysis accounts for less than 50 percent of all the variables in the model, the study is free from significant common method bias effect. All items measuring variables in this study were entered into an exploratory factor analysis with a principal axis factoring analysis, extracting seven factors, with factor 1 accounting for only 32.636 percent of the variance (the
Table is attached as Appendix A). The results indicated that no single factor emerged and no one general factor accounted for most of the covariance among the latent factors. Therefore, CMB does not affect the results of this study.

\section{Regression Model Results}

Regression analysis was used to estimate the firm level determinants of CSR among SMEs. The empirical results (see Table 3) of this study showed that managerial competence had a significant positive relationship with corporate social performance. This output supports the assertion by Belkaoui and Karpik (1989) that one of the most important determinants of a firm's pursuit of social activities that addresses societal concerns is managerial competence. It seems managers with the competence of running profitable firms also have a better understanding of the ramifications of social responsibility, which leads to them addressing more social and environmental concerns. Competent managers know that by being socially responsible this could lead to several positive 
outcomes, such as retaining and attracting competent employees, customer loyalty and good reputation, that can lead to better corporate financial performance.

Also, financial performance had a significant positive relationship with CSR. From the slack resource theory, it can be reasoned that profitable firms are more likely to have spare financial resources that can be devoted towards CSR activities (Campbell, 2007; Waddock \& Graves, 1997). In view of the credit constraints confronting SMEs in the sub-Saharan African region, it is unlikely that less financially sound SMEs would seek to undertake CSR initiatives. Regarding leverage, it had a significant negative relationship with CSR. From the narration on how financial performance influences CSR, it is rational for highly leveraged firms to be less interested in CSR activities. Firms with high leverage positions signal weak financial performance in view of high debt interest expenses they are faced with (Zweibel, 1996). This clearly discourages investment in CSR among firms that have the object of maximising wealth (Moussu \& Ohana, 2016).

Both firm age and firm size had no significant relationship with CSR. These results are contrary to previously held positions (see Meznar \& Nigh, 1995; Godos-Díez et al., 2011) that older and larger firms normally tend to be more socially responsible, because of the pressure to maintain their reputation and meet stakeholder expectations. This finding is not surprising given the context of this study. One of the major constraints confronting SMEs in Ghana is access to affordable credit, hence financial resources, as argued by slack resource theory, is a major determinant of the initiatives that firms in this sector can embark upon. Also, given that SMEs in developing countries do not normally engage in succession planning and effective financial record keeping to profit from the advantages that come with growing old and larger, it is to be expected that firm age and firm size will not have any influence on the social performance. 
Table 3: Regression Model Results

\begin{tabular}{|c|c|c|c|c|}
\hline Variable & Coefficient & Standard & t-value & Significance \\
\hline & & CIIOI & & \\
\hline Firm age & 0.007 & 0.002 & 0.152 & 0.897 \\
\hline Firm size & -0.023 & 0.002 & -0.542 & 0.588 \\
\hline $\begin{array}{l}\text { Managerial } \\
\text { competence }\end{array}$ & 0.573 & 0.043 & 14.825 & 0.000 \\
\hline Leverage & 0.169 & 0.027 & 4.021 & 0.000 \\
\hline $\begin{array}{l}\text { Financial } \\
\text { performance }\end{array}$ & 0.081 & 0.019 & 2.027 & 0.043 \\
\hline $\mathrm{R}^{2}$ & 0.446 & & & \\
\hline $\begin{array}{l}\text { Standard error } \\
\text { of regression }\end{array}$ & 0.439 & & & \\
\hline F-statistic & 67.035 & & & \\
\hline $\begin{array}{l}\text { F-statistic } \\
\text { probability }\end{array}$ & 0.000 & & & \\
\hline
\end{tabular}

\section{Conclusion}

This study examined the firm-level determinants of CSR among SMEs in Ghana. The empirical results revealed that managerial competence and financial performance have significant positive relationships with CSR, while leverage had a significant negative relationship with CSR. Firm age and firm size had no significant relationship with CSR. The thrust of this study is that, besides managerial competence, financial performance variables were far more important determinants of the social performance of SMEs than non-financial ones. The findings largely affirm the slack resource theory and the resourcebased view that the resources available to an organization is a key indicator of the kinds of strategies and activities that organisations can pursue. Based on the findings, internal resources, such as managerial competence and financial resources, are necessary for SMEs to become more socially responsible. 
Therefore, it is recommended that SME owners and managers should seek to develop and improve their managerial competencies in order to improve their social performance of their firms. They are also to balance their quest of seeking to project their enterprises as good corporate citizens with the responsibility of ensuring that these firms remain profitable. The finding shows that it is when they remain profitable that they can embark on CSR programmes. In addition, policy makers that desire active participation of the SME sector in addressing social problems should institute measures that will enhance their financial performance. These may include providing cheaper alternative to accessing funds and maintaining a stable macroeconomic environment that supports their financial success and prosperity.

Despite the major contributions this study makes to the existing SME literature, there are still some limitations that future studies may seek to address. First, the study was restricted to our understanding of how firm- level characteristics of firms influence their social performance. However, it has been posited that national and industry-level variables also have significant influence on the extent to which firms engage in social initiatives. Therefore, a comprehensive study can be carried out to establish how these other indicators impact on the social performance of SMEs. Second, it failed to disaggregate the various dimensions of CSR (i.e. social, environmental, governmental, etc). Hence, future studies could seek to examine how firm-level attributes of SMEs affect these specific areas of CSR. Finally, besides managerial competence, there are other several CSR-related competencies that could influence the ability of a manager to effectively initiate and execute CSR programmes. Future studies may want to address how other types of competencies and skills influence a manager's willingness to pursue CSR initiatives. 


\section{References}

Acabado, D. R., Branca, A. S., Catalão-Lopes, M., \& Pina, J. P. (2019). Do distinct CSR categories have distinct determinants? The Roles of Market Structure and Firm Size. European Management Review. DOI:

10.1111/emre.12341.

Adams, M., \& Hardwick, P. (1998). An analysis of corporate donations: United Kingdom evidence. Journal of Management Studies, 35(5), 641-654.

Al-Gamrh, B., \& Al-dhamari, R. (2016). Firm characteristics and corporate social responsibility disclosure in Saudi

Arabia. International

Business

Management, 10(18), 4283-4291.

Ansong, A. (2015). Effects of corporate governance on financial performance of small and medium scale enterprises in the Accra metropolis,

Ghana (Doctoral

dissertation, University of Cape Coast).

Ansong, A. (2017a). Corporate social responsibility and access to finance among Ghanaian SMEs: The role of stakeholder engagement. Cogent Business \& Management, 4(1), 1385165.

Ansong, A. (2017b). Corporate social responsibility and firm performance of Ghanaian SMEs: The role of stakeholder engagement. Cogent Business \& Management, 4(1), 1333704.

Ansong, A. (2017c). Managerial competence and financial performance of SMEs: the contingent role of stakeholder engagement. EuroMed Journal of Management, 2(1), 2-14. Artiach, T., Lee, D., Nelson, D., \& Walker, J. (2010). The determinants of corporate sustainability 
performance' Accounting \& Finance, 50(1), 31-51.

Baldini, M., Dal Maso, L., Liberatore, G., Mazzi, F., \& Terzani, S. (2018). Role of country-and firmlevel determinants in environmental, social, and governance disclosure. Journal of Business Ethics, 150(1), 79-98.

Baron, D. P. (2012). The industrial organization of private politics. Quarterly

Journal of Political Science, 7(2), 135-174.

Baumann-Pauly, D., Wickert, C., Spence, L. J., \& Scherer, A. G. (2013). Organizing corporate social responsibility in small and large firms: Size matters. Journal of Business Ethics, 115(4), 693-705.

Bénabou, R., \& Tirole, J. (2010). Individual and corporate social

responsibility. Economic a, 77(305), 1-19.

Brammer, S., \& Millington, A. (2006) Firm size, organizational visibility and corporate philanthropy: An empirical analysis. Business Ethics: A European Review, 15(1), 6-18.

Belkaoui, A., \& Karpik, P. G. (1989). Determinants of the corporate decision to disclose social information. Accounting, Auditing \& Accountability Journal, 2(1), 36-51.

Bocquet, R., Le Bas, C., Mothe, C., \& Poussing, N. (2017) 'CSR, innovation, and firm performance in sluggish growth contexts: A firm-level empirical analysis'. Journal of Business Ethics, 146(1), 241-254.

Buchholtz, A. K., Amason, A. C., \& Rutherford, M. A. (1999). Beyond resources: The mediating effect of top management discretion and values on corporate philanthropy. Business \& Society, 38(2), 167-187.

Burton, B., \& Goldsby, M. (2009). Corporate social 
responsibility orientation, goals and behavior: A study of small business owners. Business \& Society, 48(1), 88-104.

Campbell, B. (2012). Corporate social responsibility and development in Africa: Redefining the roles and responsibilities of public and private actors in the mining sector. Resources Policy, 37(2), 138-143.

Campbell, J. L. (2007). Why would corporations behave in socially responsible ways? An institutional theory of corporate social responsibility. Academy of management Review, 32(3), 946-967.

Carroll, A. (1979). A threedimensional conceptual model of corporate social performance'. Academy of Management Review, 4(1), 497-505.

Catalão-Lopes, M., Pina, J. P., \& Branca, A. S. (2016). Social responsibility, corporate giving and the tide. Management
Decision, 54(9), $\quad$ 22942309.

Chih, H. L., Chih, H. H., \& Chen, T. Y. (2010). On the determinants of corporate social responsibility: International evidence on the financial industry. Journal of Business Ethics, 93(1), 115-135.

Cochran, P. L., \& Wood, R. A. (1984). Corporate social responsibility and financial performance. Academy of management Journal, 27(1), 42-56.

Darnall, N., Henriques, I., \& Sadorsky, P. (2010). Adopting proactive environmental strategy: The influence of stakeholders and firm size. Journal of management studies, 47(6), 10721094.

Davis, K. (1973). The case for and against business assumption of social responsibilities. Academy of Management Journal, 16(1), 312-322.

Davis, J. H., Schoorman, F. D., \& Donaldson, L. (1997). 
Toward a stewardship theory of management. Academy of Management review, 22(1), 20-47.

Diamond, D. W. (1989). Reputation acquisition in debt markets. Journal of political Economy, 97(4), 828-862.

Doty, D. H., \& Glick, W. H. (1998).

Common methods bias: does common methods variance really bias results?. Organizational Research Methods, 1(4), 374-406.

Fauzi, H., \& Idris, K. (2009). The relationship of CSR and financial performance: New evidence from Indonesian companies. Issues in Social and Environmental Accounting, 3(1), 66-87.

Fox, J. (1991). Regression diagnostics: An introduction. New Castle Upon Tyne: Sage Publications.

Frederick, W. (1986). Theories of corporate social performance. Working
Paper, University of Pittsburgh, Graduate School of Business. Freeman, R. E. (1984). Strategic management: $\quad A$ stakeholder approach. Pitman: Boston.

Friedman, M. (1970). The social responsibility of business is to increase its profits. New York Times Magazine, September 13th, 32-33, 122, 126.

Garriga, E., \& Melé, D. (2004). Corporate social responsibility theories: Mapping the territory. Journal of business ethics, 53(1), 51-71.

Godos-Díez, J. L., FernándezGago, R., \& MartínezCampillo, A. (2011). How important are CEOs to CSR practices? An analysis of the mediating effect of the perceived role of ethics and social responsibility. Journal of Business Ethics, 98(4), 531-548.

Harris, L. C., \& Crane, A. (2002). The greening of organizational culture: Management views on 
the depth, degree and diffusion of change. Journal of organizational change management, 15(3), 214-234.

Harrison, J. S., \& Coombs, J. E. (2006).

Financial leverage and social performance. In Academy of Management Proceedings (Vol. 2006, No. 1, pp. F1-F6). Briarcliff Manor, NY 10510: Academy of Management.

Hernandez, M. (2008). Promoting stewardship behavior in organizations: leadership model. Journal of Business Ethics, 80(1), 121-128.

Ho, F. N., Wang, H. M. D., HoDac, N., \& Vitell, S. J. (2019). Nature and relationship between corporate social performance and firm size: a cross-national study. Social

Responsibility

Journal, 15(2), 258-274.

Holton, I., Glass, J., \& Price, A. D. F. (2010). Managing for sustainability: Findings from four company case studies in the UK precast concrete industry. Journal of Cleaner Production, 18(1), 152160.

Hunt, C. B., \& Auster, E. R. (1990). Proactive environmental management: avoiding the toxic trap. MIT Sloan Management Review, 31(2), 7-18.

Ioannou, I., \& Serafeim, G. (2012). What drives corporate social performance? The role of nation-level institutions. Journal of International Business Studies, 43(9), 834-864.

Jensen, M. C. (2002). Value maximization, stakeholder theory, and the corporate objective function. Business ethics quarterly, 12(2), 235256.

Jensen, M. C., \& Meckling, W. H. (1976). Theory of the firm: Managerial behavior, agency costs and ownership structure. Journal of financial 
economics, 3(4), 305360.

Johnson, R. A., \& Greening, D. W. (1999). The effects of corporate governance and institutional ownership types on corporate social performance. Academy of management journal, 42(5), 564-576.

Jones, M. T. (1999). The institutional determinants of social responsibility. Journal of Business Ethics, 20(2), 163-179.

Kock, N., \& Lynn, G. (2012). Lateral collinearity and misleading results in variance-based SEM: An illustration and recommendations. Journ al of the Association for Information Systems, 13(7), 546-580.

Krejcie, R. V., \& Morgan, D. W. (1970). Determining sample size for research activities. Educational and Psychological Measurement, 30(1), 607-610.

Lans, T., Blok, V., \& Wesselink, R. (2014). Learning apart and together: Towards an integrated competence framework for sustainable entrepreneurship in higher education. Journal of Cleaner Production, 62(1), 37-47.

Lepoutre, J., and Heene, A. (2006). Investigating the impact of firm size on small business social responsibility: A critical review. Journal of business ethics, 67(3), 257-273.

Lin, C. H., Yang, H. L., \& Liou, D. Y. (2009). The impact of corporate social responsibility on financial performance: Evidence from business in Taiwan. Technology in Society, 31(1), 56-63.

Lourenço, I. C., \& Branco, M. C. (2013). Determinants of corporate sustainability performance in emerging markets: the Brazilian case. Journal of Cleaner Production, 57, 134-141. Mackey, A., Mackey, T. B., \& Barney, J. B. (2007). Corporate social responsibility and firm 
performance: Investor preferences and corporate strategies. Academy of management review, 32(3), 817-835.

Madueno, J. H., Jorge, M. L., Conesa, I. M., \& Martínez-Martínez, D. (2016). Relationship between corporate social responsibility and competitive performance in Spanish SMEs: Empirical evidence from a stakeholders' perspective. $\quad B R Q$ Business Research Quarterly, 19(1), 55-72.

Mamic, I. (2005). Managing global supply chain: The sports footwear, apparel and retail sectors. Journal of Business Ethics, 59(1), 81-100.

Man, T.W.Y

(2011)

Entrepreneurial

competencies and the performance of small and medium

enterprises in the Hong Kong services sector. (Doctoral Dissertation, Hong Kong Polytechnic University).
Margolis, J. D., \& Walsh, J. P. (2003). Misery loves companies: Rethinking social initiatives by business. Administrative science quarterly, 48(2), 268-305.

Mat Roni, S. (2014). Introduction to SPSS. Edith Cowan University, SOAR Centre, Australia.

McElroy, K. M., \& Siegfried, J. J. (1985). The effect of firm size on corporate philanthropy. Quarterly Review of Economics and Business, 25(2), 18-26.

McWilliams, A., \& Siegel, D. (2000). Corporate social responsibility and financial performance'. Strategic Management Journal, 21(5), 603-609.

McWilliams, A., \& Siegel, D. (2001).

Profit maximizing corporate social responsibility. Academy of Management Review, 26(4), 504-505.

Meznar, M. B., \& Nigh, D. (1995). Buffer or bridge? Environmental and organizational determinants of public 
affairs activities in

American

firms.

Academy of Management Journal, 38(4), 975-996.

Mishra, S., \& Modi, S. B. (2013)

'Positive and negative corporate social responsibility, financial leverage, and idiosyncratic

risk'. Journal of business ethics, 117(2), 431-448.

Mishra, S., \& Suar, D. (2010). Does corporate social responsibility influence firm performance of Indian

companies? Journal of business ethics, 95(4), 571-601.

Moussu, C., \& Ohana, S. (2016). Do leveraged firms underinvest in corporate social responsibility? Evidence from health and safety programs in US firms. Journal of Business Ethics, 135(4), 715-729.

Nakiyingi, J. (2010). Managerial competencies, access to credit and business success (Doctoral dissertation, Makerere University).

Pallant, J. (2015). SPSS Survival Manual. Berkshire: Open University Press.

Podsakoff, P. M., MacKenzie, S. B., \& Podsakoff, N. P. (2012). Sources of method bias in

social science research and recommendations on how to control it. Annual Review of Psychology, 63, 539-569. Podsakoff, P. M., MacKenzie, S. B., Lee, J. Y., \& Podsakoff, N. P. (2003). Common method biases in behavioral research: A critical review of the literature and recommended remedies. Journal of Applied Psychology, 88(5), 879.

Preston, L.E. and Post, J.E. (1975) 'Private management and public policy. The principle of public responsibility'. Prentice Hall: Englewood Cliffs, NJ.

Purushothaman, M. A. Y. A., Tower, G., Hancock, P., 
\& Taplin, R. (2000).

Determinants

of

corporate social reporting

practices of listed

Singapore

companies. Pacific

Accounting

Review, 12(2), 101.

Reverte, C. (2009). Determinants

of corporate social responsibility disclosure ratings by Spanish listed

firms. Journal of

Business Ethics, 88(2),

351-366.

Roberts, R. W. (1992).

Determinants of

corporate social

responsibility disclosure:

An application of

stakeholder theory.

Accounting,

organizations

and

society, 17(6), 595-612.

Sahut, J. M., Mili, M., Ben

Tekaya, S., \& Teulon, F.

(2016). Financial impacts and antecedents of CSR: a PLS Path Modelling Approach. Economics Bulletin, 36(2), 736-751.

Salancik, G. R., \& Pfeffer, J. (1978). A social information processing approach to job attitudes and task design. Administrative science quarterly, 23(2), 224253.

Saeidi, S. P., Sofian, S., Saeidi, P., Saeidi, S. P., \& Saaeidi, S. A. (2015). How does corporate social responsibility contribute to firm financial performance? The mediating role of competitive advantage, reputation, and customer satisfaction. Journal of business research, 68(2), 341-350.

Shleifer, A. (2004). Does competition destroy ethical behavior? No. w10269, National Bureau of Economic Research.

Singhapakdi, A., Gopinath, M., Marta, J. K., \& Carter, L. L. (2008). Antecedents and consequences of perceived importance of ethics in marketing situations: A study of Thai businesspeople. Journal of Business Ethics, 81(4), 887-904. 
Spence, L.J. \& Lozano, J.F. (2000). Communicating about ethics with small firms. Experiences from U.K. and Spain. Journal of Business Ethics, 27(1/2), 43-53.

Stanwick, P. A., \& Stanwick, S. D. (1998). The determinants of corporate social performance:

An

empirical

examination. American

Business Review, 16(1), 86.

Swanson, D. L. (2008). Top managers as drivers for corporate social responsibility. The

Oxford handbook of corporate social responsibility, 227-248.

Sweeney, L. (2009). A study of current practice of corporate social responsibility (CSR) and an examination of the relationship between CSR and financial performance using structural equation modeling (SEM),

(Doctoral Dissertation,
Dublin Institute of Technology).

Titman, S. (1984). The effect of capital structure on a firm's liquidation decision.' Journal of financial economics, 13(1), $\quad$ 137151.

Quazi, A. M. (2003). Identifying the determinants of corporate managers' perceived social obligations. Management Decision, 41(9), 822-831.

Udayasankar, K. (2008). Corporate social responsibility and firm size. Journal of Business Ethics, 83(2), 167-175.

Waddock, S.A. \& Graves, S.B., (1997). The corporate social performancefinancial performance link. Strategic

Management

Journal, 18(4), 303-319.

Waldman, D. A., De Luque, M. S., Washburn, N., House, R. J., Adetoun, B., Barrasa, A., \& Dorfman, P. (2006). Cultural and leadership predictors of corporate social 
responsibility values of top management: A GLOBE study of 15 countries. Journal of International Business Studies, 37(6), 823-837.

Wals, A. E. J., \& Jickling, B. (2002). Sustainability in higher education: From double-think and newspeak to critical thinking and meaningful learning. Higher Education Policy, 15(1), 121-131.

Wanderley, L. S. O., Lucian, R., Farache, F., \& de Sousa Filho, J. M. 2008. CSR information disclosure on the web: a context-based approach analysing the influence of country of origin and industry sector. Journal of Business Ethics, 82(2), 369-378.

Wickert, C., Scherer, A. G., \& Spence, L. J. (2016). Walking and talking corporate social responsibility:

Implications of firm size and organizational cost. Journal

of

Management

Studies, 53(7), $1169-$ 1196.

Withisuphakorn, P., \& Jiraporn, P. (2016). The effect of firm maturity on corporate social responsibility (CSR): do older firms invest more in CSR?. Applied Economics Letters, 23(4), 298-301.

Zhu, Y., Sun, L. Y., \& Leung, A. S. (2014). Corporate social responsibility, firm reputation, and firm performance: The role of ethical leadership. Asia Pacific Journal of Management, 31(4), 925947.

Zwiebel, J. (1996). Dynamic capital structure under managerial entrenchment. The American Economic Review, 86(5), 11971215. 
A. Ansong: Firm-Level Determinants of Corporate Social Responsibility: Evidence from Small and Medium-sized Enterprises in Ghana

\section{Appendix a: Common Method Bias ExtractioN}

Total Variance Explained

\begin{tabular}{|c|c|c|c|c|c|c|}
\hline \multirow[b]{2}{*}{$\begin{array}{l}\text { Compon } \\
\text { ent }\end{array}$} & \multicolumn{3}{|c|}{ Initial Eigenvalues } & \multicolumn{3}{|c|}{$\begin{array}{c}\text { Extraction Sums of Squared } \\
\text { Loadings }\end{array}$} \\
\hline & Total & $\begin{array}{c}\% \text { of } \\
\text { Variance }\end{array}$ & $\begin{array}{l}\text { Cumulati } \\
\text { ve } \%\end{array}$ & Total & $\begin{array}{c}\% \text { of } \\
\text { Variance }\end{array}$ & $\begin{array}{l}\text { Cumulati } \\
\text { ve } \%\end{array}$ \\
\hline 1 & $\begin{array}{r}10.11 \\
7\end{array}$ & 32.636 & 32.636 & 10.117 & 32.636 & 32.636 \\
\hline 2 & 2.684 & 8.659 & 41.295 & & & \\
\hline 3 & 1.954 & 6.303 & 47.598 & & & \\
\hline 4 & 1.601 & 5.164 & 52.762 & & & \\
\hline 5 & 1.490 & 4.806 & 57.568 & & & \\
\hline 6 & 1.165 & 3.759 & 61.326 & & & \\
\hline 7 & 1.027 & 3.312 & 64.639 & & & \\
\hline 8 & .945 & 3.050 & 67.688 & & & \\
\hline 9 & .783 & 2.525 & 70.213 & & & \\
\hline 10 & .718 & 2.317 & 72.530 & & & \\
\hline 11 & .671 & 2.163 & 74.693 & & & \\
\hline 12 & .649 & 2.092 & 76.786 & & & \\
\hline 13 & .616 & 1.988 & 78.774 & & & \\
\hline
\end{tabular}


A. Ansong: Firm-Level Determinants of Corporate Social Responsibility: Evidence from Small and Medium-sized Enterprises in Ghana

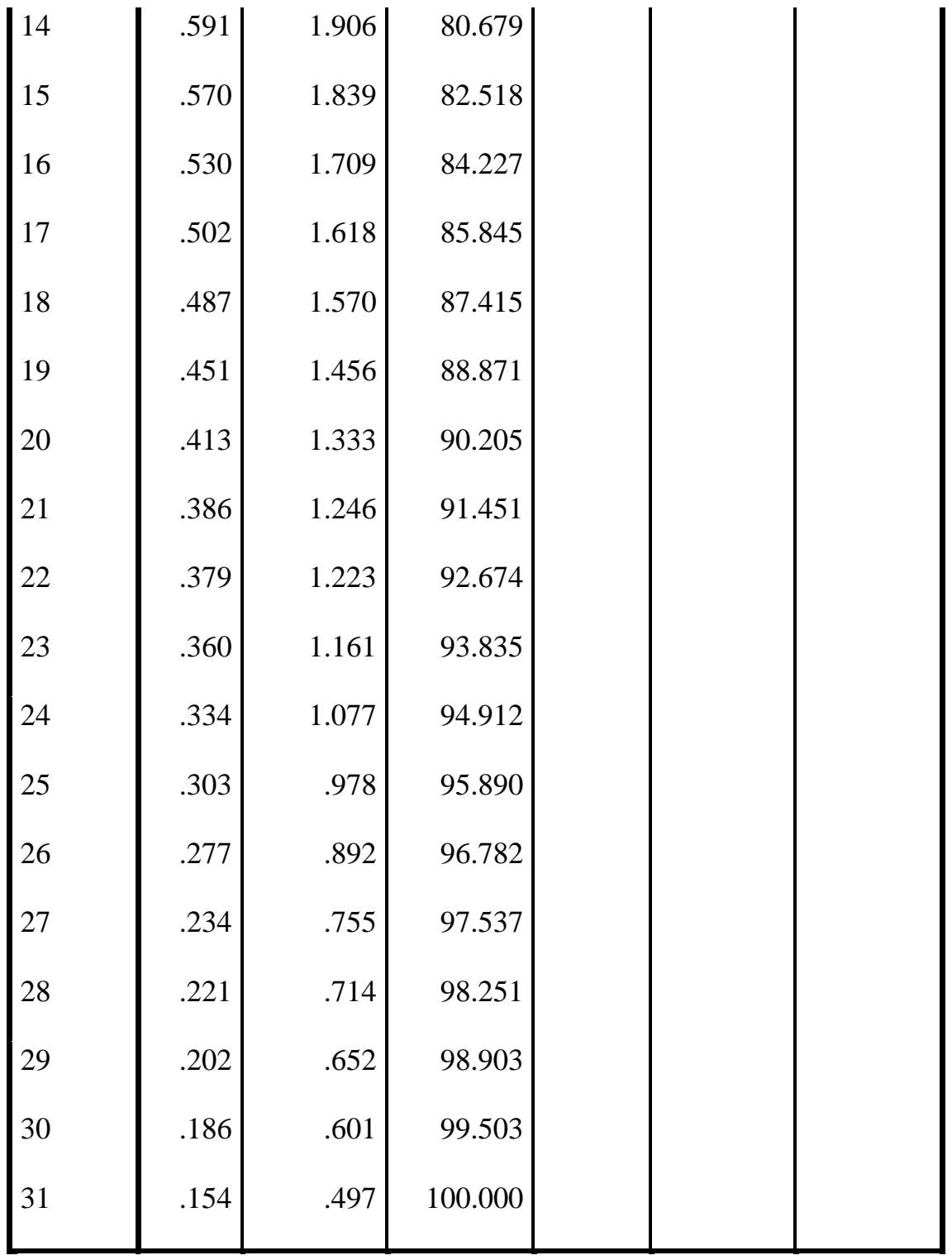

Extraction Method: Principal Component Analysis. 